\title{
Analisis Permintaan Dengan Pendekatan Maslahah
}

\author{
Mashuri \\ Kantor Urusan Agama (KUA) Baranti Sidrap \\ mashuri@stainparepare.ac.id
}

\begin{abstract}
Abstrak
Artikel ini mengkaji teori permintaan dan penawaran yang saling bertemu dan membentuk satu titik pertemuan dalam satuan harga dengan pendekatan maslahah. Maslahah merupakan tujuan utama dalam mengkonsumsi barang, sebab maksimasi maslahah merupakan cara untuk mencapai falah. Pengaruh maslahah terhadap permintaan tidak bisa dijelaskan secara sederhana, sebagaimana pengaruh faktor-faktor lainnya, sebab ia akan tergantung pada tingkat keimanan. Jika mereka melihat barang dengan kandungan berkah yang tinggi, maka mereka akan meninggalkan barang dengan kandungan berkah yang rendah dan menggantinya dengan barang dengan kandungan berkahnya lebih tinggi. Dengan demikian, jika maslahah relatif turun, maka jumlah barang yang diminta akan turun juga, begitu juga sebaliknya.
\end{abstract}

Kata Kunci: Teori, Permintaan, Maslahah

\section{Pendahuluan}

Dalam kajian ekonomi secara mikro, pembahasan didasarkan pada perilaku individu sebagai pelaku ekonomi yang berperan menentukan tingkat harga dalam proses mekanisme pasar. Mekanisme pasar itu sendiri adalah interaksi yang terjadi antara permintaan (demand) dari sisi konsumen dan penawaran (supply) dari sisi produsen, sehingga harga yang diciptakan merupakan perpaduan dari kekuatan masing-masing pihak tersebut. Oleh karena itu, maka perilaku permintaan dan penawaran merupakan konsep dasar dari kegiatan ekonomi yang lebih luas.

Pandangan ekonomi Islam mengenai permintaan, penawaran dan mekanisme pasar ini relatif sama dengan ekonomi konvensional, namun terdapat batasan-batasan dari individu untuk berperilaku ekonomi yang sesuai dengan aturan syariah. Dalam ekonomi islam, norma dan moral "Islami" yang merupakan prinsip Islam dalam berekonomi, merupakan faktor 
yang menentukan suatu individu maupun masyarakat dalam melakukan kegiatan ekonominya sehingga teori ekonomi yang terjadi menjadi berbeda dengan teori pada ekonomi konvensional.

Dewasa ini, banyak sekali kekeliruan konsumen dalam menentukan pilihan dalam memenuhi kebutuhannya. Konsumen lebih mementingkan kepuasan dalam memilih barang/jasa yang diinginkannya, tanpa memikirkan maslahah dan berkah yang terkandung di dalam barang tersebut. Yang seharusnya barang yang dibeli dapat memberikan manfaat kepada mereka malah sebaliknya dapat menjadi mudharat bagi mereka, dan menurunkan derajat manusia karena salah dalam pilihan kebutuhannya. Batasan-batasan yang harus diperhatikan dalam memilih barang/jasa salah satunya adalah tidak berlebih-lebihan (israf) dan mempertimbangkan kebutuhan orang lain juga. Karena kepedulian kita terhadap orang lain ini dimaknai sebagai bentuk amal saleh, dan juga bisa dimaknai sebagai upaya memberikan kesempatan konsumen lain untuk membeli barang yang dibutuhkannya. Tulisan ini akan membahas tentang konsep umum permintaan dan penawaran dengan analisis pendekatan maslahah.

\section{Konsep Umum Permintaan}

Dalam ekonomi terdapat permintaan dan penawaran yang saling bertemu dan membentuk satu titik pertemuan dalam satuan harga dan kuantitas (jumlah barang). Setiap transaksi perdagangan pasti ada permintaan, penawaran, harga dan kuantitas yang saling mempengaruhi satu sama lain. Permintaan adalah sejumlah barang yang dibeli atau diminta pada suatu harga dan waktu tertentu. ${ }^{1}$ Didalam hukum permintaan dijelaskan bahwa makin rendah harga suatu barang maka makin banyak permintaan terhadap barang tersebut. Sebaliknya makin tinggi suatu harga barang maka

1Fadli Saldi, Hukum Permintaan dan Penawaran, http://drfadli.blogdetik.com/ files/2010/05/ hukum-permintaandanpenawaran.pdf. (Diakses pada tanggal 23 November 2018). 
makin sedikit permintaan terhadap barang tersebut. ${ }^{2}$ Faktor-faktor permintaan antara lain :

1. Harga barang itu sendiri

Jika suatu harga barang naik, produsen cenderung menambah jumlah barang yang dihasilkan.

2. Harga Barang Subtitusi.

Barang substitusi adalah barang yang dapat saling menggantikan fungsi barang lain. Sebagai contoh, kopi dan teh. Jika pada suatu waktu kopi tidak ada maka peminum kopi dapat menggantikannya dengan teh dan sebaliknya jika teh tidak ada peminum teh dapat menggantikannya dengan kopi. Harga barang substitusi dapat mempengaruhi permintaan barang yang disubstitusi. Jika harga kopi turun, maka permintaan teh menjadi turun dan sebaliknya.

3. Pendapatan rumah tangga dan pendapatan rata-rata masyarakat.

Jika pendapatan rumah tangga semakin tinggi akan diikuti daya beli konsumen. Pendapatan merupakan faktor yang sangat penting di dalam menentukan permintaan berbagai jenis barang. Perubahan pendapatan selalu menimbulkan perubahan permintaan berbagai jenis barang.

4. Corak distribusi pendapatan masyarakat

Pendapatan merupakan faktor yang sangat penting di dalam menentukan permintaan berbagai jenis barang. Perubahan pendapatan selalu menimbulkan perubahan permintaan berbagai jenis barang. Menurut sifat perubahan permintaan akibat perubahan pendapatan, berbagai jenis barang dapat dibedakan menjadi barang inferior, barang esensial, barang normal, dan barang mewah.

Barang inferior adalah barang yang umumnya diminta oleh orangorang berpendapatan rendah. Jika orang-orang tersebut bertambah pendapatannya, mereka akan mengurangi permintaannya terhadap

2 Sadono Sukirno, Mikroekonomi Teori Pengantar (Jakarta: RajaGrafindo Persada, 
barang inferior tersebut dan menggantikannya dengan barang lain yang mutunya lebih tinggi. Sebagai contoh, ubi kayu. Ketika pendapatannya rendah, orang-orang mengkonsumsi ubi kayu. Jika pendapatan mereka meningkat maka mereka akan mengurangi konsumsi ubi kayu dan menggantinya dengan beras. Barang esensial adalah barang yang sangat penting manfaatnya bagi kehidupan masyarakat sehari-hari. Contohnya makanan (beras, gula, kopi, teh) dan pakaian.

Barang normal adalah barang yang akan mengalami kenaikan permintaannya apabila terjadi kenaikan pendapatan masyarakat. Sebagian besar barang yang ada, umumnya termasuk barang normal, seperti perabot rumah-tangga, pakaian, dan beberapa makanan. Barang mewah adalah barang-barang yang dibeli oleh orang-orang yang berpendapatan tinggi. ${ }^{3}$ Adapun Contoh barang-barang mewah seperti mobil, emas, berlian, lukisan yang mahal, dan sebagainya.

5. Cita rasa masyarakat.

Apabila selera konsumen terhadap suatu barang dan jasa tinggi maka akan diikuti dengan jumlah barang dan jasa yang diminta akan mengalami peningkatan. Peningkatan selera konsumen selalu diikuti dengan peningkatan jumlah barang.

6. Jumlah penduduk.

Pertambahan jumlah penduduk yang diikuti oleh perkembangan kesempatan kerja secara tidak langsung akan meningkatkan permintaan suatu barang.

7. Ramalan mengenai keadaan di masa yang akan datang.

Apabila konsumen menduga harga barang akan terus mengalami kenaikan di masa datang, maka konsumen cenderung untuk menambah jumlah barang yang dibelinya. Contohnya konsumen sudah

${ }^{3}$ Kardono-hunfil, Permintaan dan Penawaran, http://nuhfil.Lecture.ub.ac.id/ files/2009/03/ mikro-2-penawaran-dan-permintaan-nuhfil.pdf. (Diaksese pada tanggal 15 November 2018). 
memprediksikan bahwa beberapa bulan kedepan harga sembako akan naik, maka dari awal konsumen akan membeli.

Ibnu Taimiyyah memberikan penjelasan yang rinci tentang beberapa faktor yang mempengaruhi permintaan dan tingkat harga diantaranya: ${ }^{4}$

a. Permintaan masyarakat (al-ragabah) yang sangat bervariasi (people's desire) terhadap barang. Faktor ini tergantung pada jumlah barang yang tersedia (al-matlub). Suatu barang akan semakin disukai jika jumlahnya relatif kecil (scarce) daripada yang banyak jumlahnya.

b. Tergantung kepada jumlah orang yang membutuhkan barang (demander/consumer/tullab). Semakin banyak jumlah peminatnya, semakin tinggi nilai suatu barang.

c. Harga juga dipengaruhi oleh kuat lemahnya kebutuhan terhadap suatu barang, selain juga besar dan kecilnya permintaan. Jika kebutuhan terhadap suatu barang kuat dan berjumlah besar, maka harga akan naik lebih tinggi jika dibandingkan dengan jika kebutuhannya lemah dan sedikit.

d. Harga juga akan bervariasi menurut kualitas pembeli barang tersebut (almu'awid). Jika pembeli merupakan orang kaya dan terpercaya (kredibel) dalam membayar kewajibannya, maka kemungkinan ia akan memperoleh tingkat harga yang lebih rendah dibandingkan dengan orang yang tidak kredibel (suka menunda kewajiban atau mengingkarinya).

e. Tingkat harga juga dipengaruhi oleh jenis uang yang digunakan sebagai alat pembayaran. Jika menggunakan jenis mata uang yang umum dipakai, maka kemungkinan harga relatif lebih rendah jika dibandingakan dengan menggunakan mata uang yang tidak umum atau kurang diterima secara luas.

4 Munrokhim Misanan dkk., Text Book Ekonomi Islam, (Yogyakarta: Direktorat Perbankan Syariah Bank Indonesia DPbS BI \& Pusat Pengkajian dan Pengembangan Ekonomi Islam Universitas Islam Indonesia (P3EI UII), h. 155-156. 
f. Hal di atas dapat terjadi karena tujuan dari suatu transaksi haruslah menguntungkan penjual dan pembeli. Jika pembeli memiliki kemampuan untuk membayar dan dapat memenuhi semua janjinya, maka transaksi akan lebih mudah atau lancar dibandingkan dengan jika pembeli tidak memiliki kemampuan membayar dan mengingkari janjinya. Tingkat kemampuan dan kredibilitas pembeli berbeda-beda. Hal ini berlaku bagi pembeli maupun penjualnya, penyewa dan yang menyewakan, dan siapa pun juga. Obyek dari suatu transaksi terkadang (secara fisik) nyata atau juga tidak nyata. Tingkat harga barang yang lebih nyata (secara fisik) akan lebih rendah dibandingkan dengan yang tidak nyata. Hal yang sama dapat diterapkan untuk pembeli yang kadang-kadang dapat membayar karena memiliki uang, tetapi kadang-kadang mereka tidak memiliki uang cash dan ingin meminjam. Harga pada kasus yang pertama kemungkinan lebih rendah daripada yang kedua.

g. Kasus yang sama dapat diterapkan pada orang yang menyewakan suatu barang. Kemungkinan ia berada pada posisi sedemikian rupa, sehingga penyewa dapat memperoleh manfaat dengan tanpa tambahan biaya apapun. Akan tetapi, kadang-kadang penyewa tidak dapat memperoleh manfaat ini jika tanpa tambahan biaya, seperti yang terjadi di desa yang dikuasai penindas atau oleh perampok, atau di suatu tempat diganggu oleh binatang-binatang pemangsa. Sebenarnya, harga sewa tanah seperti itu tidaklah sama dengan harga tanah yang tidak membutuhkan biaya-biaya tambahan ini. 5

Selain faktor-faktor permintaan, adapun macam-macam permintaan yaitu:

1. Dilihat dari daya beli konsumen, permintaan dikelompokkan sebagai berikut:

5 Munrokhim Misanan dkk., Text Book Ekonomi Islam, (Yogyakarta: Direktorat Perbankan Syariah Bank Indonesia DPbS BI \& Pusat Pengkajian dan Pengembangan Ekonomi Islam Universitas Islam Indonesia (P3EI UII), h. 155-156. 
a. Permintaan efektif, merupakan permintaan konsumen terhadap suatu barang dan jasa yang disertai daya beli atau kemampuan membayar.

b. Permintaan potensial, merupakan permintaan konsumen terhadap suatu barang dan jasa yang tidak disertai dengan daya beli atau hanya mendasarkan pada kebutuhan saja.

2. Dilihat dari pendapatan nyata konsumen, permintaan dikelompokkan sebagai berikut:

a. Permintaan konsumen, yaitu permintaan yang dilakukan oleh seluruh anggota masyarakat terhadap barang dan jasa untuk memenuhi kebutuhan.

b. Permintaan pengusaha, yaitu berawal dari pengusaha berusaha memproduksi barang dan jasa yang dibutuhkan konsumen.

c. Permintaan pemerintah, bertitik-tolak dari pemerintah mengeluarkan belanja untuk kelancaran roda pemerintahan sehingga menimbulkan permintaan pemerintah terhadap barang-barang dan jasa.

d. Permintaan luar negeri, terbentuk dari permintaan yang datang dari konsumen, pengusaha, dan pemerintah negara lain sehingga mempengaruhi pula permintaan di dalam negeri.

3. Dilihat dari jumlah pemintaan konsumen, permintaan dikelompokkan sebagai berikut:

a. Permintaan perseorangan, merupakan permintaan dari seseorang untuk memenuhi kebutuhan hidup, bersifat beda antara orang yang satu dengan yang lain, tergantung dari pendapatan dan pendidikan.

b. Permintaan pasar atau kolektif, merupakan permintaan yang dimiliki masyarakat sebagai keseiuruhan dalam waktu yang sama. ${ }^{6}$

Definisi dan faktor-faktor yang mempengaruhi terhadap permintaan, antara permintaan konvensional dan islam mempunyai kesamaan. Ini

\footnotetext{
6Ekonomi Holic, Permintaan Penawaran dan Harga Keseimbangan, http://www.ekonomiholic.com/2015/01/permintaan-penawaran-hargakeseimbangan.html. (Diakses pada tanggal 17 Februari 2018).
} 
dikarenakan bahwa keduanya merupakan hasil dari penelitian kenyataan dilapangan (empiris) dari tiap-tiap unit ekonomi. Namun terdapat perbedaan yang mendasar di antara keduanya, diantaranya: ${ }^{7}$

1. Perbedaan utama antara kedua teori tersebut tentunya adalah mengenai sumber hukum dan adanya batasan syariah dalam teori permintaan islami. Permintaan Islam berprinsip pada entitas utamanya yaitu Islam sebagai pedoman hidup yang langsung dibimbing oleh Allah SWT. Permintaan Islam secara jelas mengakui bahwa sumber ilmu tidak hanya berasal dari pengalaman berupa data-data yang kemudian mengkristal menjadi teori-teori, tapi juga berasal dari firman-firman Tuhan (revelation), yang menggambarkan bahwa ekonomi Islam didominasi oleh variabel keyakinan religi dalam mekanisme sistemnya.

2. Teori ekonomi yang dikembangkan barat membatasi analisisnya dalam jangka pendek yakni hanya sejauh bagaimana manusia memenuhi keinginannya saja. Tidak ada analisis yang memasukkn nilai-nilai moral dan sosial. Analisis hanya dibatasi pada variabel-variabel pasar semata, seperti harga, pendapatan dan sebagainya. Variabel-variabel lainnya tidak dimasukkan, seperti variabel nilai moral seperti kesederhanaan, keadilan, sikap mendahulukan orang lain. Dalam ekonomi konvensional filosofi dasarnya terfokus pada tujuan keuntungan dan materialme. Hal ini wajar saja karena sumber inspirasi ekonomi konvensional adalah akal manusia yang tergambar pada daya kreatifitas, daya olah informasi dan imajinasi manusia. Padahal akal manusia merupakan ciptaan Tuhan, dan memiliki keterbatasan bila dibandingkan dengan kemampuan.

3. Konsep permintaan dalam Islam menilai suatu komoditi tidak semuanya bisa untuk dikonsumsi maupun digunakan, dibedakan antara yang halal maupun yang haram. Allah telah berfirman dalam Surat Al-Maidah/5: 8788:

${ }^{7}$ Bulan Purnama, Teori Permintaan Islami, http://makalahkite.blogspot.co.id/ 2013/12/teori-permintaan-islami.html (Diakses pada tanggal 22 November 2018) 
Terjemahnya:

"Hai orang-orang yang beriman, janganlah kamu haramkan apa-apa yang baik yang telah Allah halalkan bagi kamu, dan janganlah kamu melampaui batas. Sesungguhnya Allah tidak menyukai orang-orang yang melampaui batas. Dan makanlah makanan yang halal lagi baik dari apa yang Allah telah rezekikan kepadamu, dan bertakwalah kepada Allah yang kamu beriman kepada-Nya" ${ }^{8}$

Oleh karenanya dalam teori permintaan Islami membahas permintaan barang halal, barang haram, dan hubungan antara keduanya. Sedangkan dalam permintaan konvensional, semua komoditi dinilai sama, bisa dikonsumsi atau digunakan.

4. Dalam motif permintaan Islam menekankan pada tingkat kebutuhan konsumen terhadap barang tersebut sedangkan motif permintaan konvensional lebih didominasi oleh nilai-nilai kepuasan (interest). Konvensional menilai bahwa egoisme merupakan nilai yang konsisten dalam mempengaruhi seluruh aktivitas manusia.

5. Permintaan Islam bertujuan mendapatkan kesejahteraan atau kemenangan akhirat (falah) sebagai turunan dari keyakinan bahwa ada kehidupan yang abadi setelah kematian yaitu kehidupan akhirat, sehingga anggaran yang ada harus disisihkan sebagai bekal untuk kehidupan akhirat. ${ }^{9}$

\section{Analisis Pendekatan Maslahah terhadap Permintaan}

Permintaan adalah sejumlah barang yang diminta oleh konsumen pada berbagai tingkat harga pada periode tertentu. ${ }^{10}$ Permintaan adalah keinginan yang disertai kemampuan untuk membeli barang dan jasa pada tingkat harga dalam

8 Kementerian Agama RI, Al-Qur'an Tajwid (Jakarta: Sygma Examedia Arkanleema, 2010), h. 122.

${ }^{9}$ Bulan Purnama, Teori Permintaan Islami, http://makalahkite.blogspot.co.id/2013/ 12/teori-permintaan-islami.html (Diakses pada tanggal 22 November 2018)

10 Tri Kusnawangsih Pracoyo, dan Antyo Pracoyo, Aspek Dasar Ekonomi Mikro (Jakarta: PT Grasindo, 2006), h. 29. 
waktu tertentu. ${ }^{11}$ Permintaan secara umum adalah sejumlah barang yang dibeli atau diminta pada suatu harga dan waktu tertentu. Menurut Ibnu Taimiyyah, permintaan suatu barang adalah hasrat terhadap sesuatu, yang digambarkan dengan istilah raghbah fil al-syai. ${ }^{12}$ Diartikan juga sebagai jumlah barang yang diminta. Dalam suatu perekonomian, permintaan merupakan keinginan dari masyarakat sebagai konsumen. Keinginan konsumen tersebut di pasar sangat tinggi, akan tetapi pada kenyataannya kemampuan konsumen untuk memenuhi keinginan tersebut terbatas.

Ada tiga hal penting yang perlu diperhatikan dalam konsep permintaan, yaitu: ${ }^{13}$

1. Jumlah yang diminta merupakan kuantitas yang diinginkan.

2. Apa yang diinginkan tidak merupakan harapan kosong tetapi merupakan permintaan yang efektif.

3. Kuantitas yang diminta merupakan arus pembelian yang kontinyu.

Secara garis besar, permintaan dalam ekonomi Islam sama dengan ekonomi konvensional, namun ada prinsip-prinsip tertentu yang harus diperhatikan oleh individu muslim dalam keinginannya.

Faktor-faktor yang mempengaruhi permintaan ${ }^{14}$ yaitu:

1. Harga barang yang bersangkutan

Harga barang yang bersangkutan merupakan determinan penting dalam permintaan. Pada umumnya, hubungan antara tingkat harga dan jumlah permintaan adalah negatif. Semakin tinggi tingkat harga, maka semakin rendah.

2. Harga barang lain yang terkait

${ }^{11}$ Suparmoko, Ekonomi (Bogor: Quadra, 2007), h. 37

12 Anita Rahmawati, Ekonomi Mikro Islam (Kudus: Nora Media Enterprise, 2011), h. 89

13 Richarg G Lipsey, et., al, eds, Pengantar Makroekonomi (Jakarta: Erlangga, 1993), h.

${ }^{14}$ Anita Rahmawati, Ekonomi Mikro Islam, h. 89-93 
Harga barang lain yang terkait menentukan permintaan suatu barang. Yang dimaksud harga barang lain yang terkait adalah substitusi dan komplementer dari barang tersebut. Jika harga barang substitusinya menurun, maka permintaan terhadap barang tersebut juga turun, sebab konsumen mengalihkan permintaannya pada barang substitusi, dan sebaliknya. Sementara itu, jika harga barang komplementer naik, maka permintaan terhadap barang tersebut turun. Sebaliknya jika harga barang komplememter turun, maka permintaan terhadap barang tersebut naik.

3. Pendapatan konsumen

Perubahan pendapatan selalu menimbulkan perubahan permintaan berbagai jenis barang. Semakin tinggi pendapatan konsumen, maka semakin tinggi daya belinya sehingga permintaan tehadap barang akan meningkat. Sebaliknya, semakin rendah pendapatan, maka semakin rendah pula daya belinya dan permintaan terhadap barang pun rendah.

4. Ekspektasi (Pengharapan)

Ekspektasi bisa berupa ekspektasi positif maupun negatif. Dalam kasus ekspektasi positif, konsumen akan lebih terdorong untuk membeli suatu barang, sememtara ekspektasi negatif akan menimbulkan akibat yang sebaliknya.

5. Maslahah ${ }^{15}$

Maslahah merupakan tujuan utama dalam mengkonsumsi barang, sebab maksimasi maslahah merupakan cara untuk mencapai falah. Pengaruh maslahah terhadap permintaan tidak bisa dijelaskan secara sederhana, sebagaimana pengaruh faktor-faktor lainnya, sebab ia akan tergantung pada tingkat keimanan. Jika mereka melihat barang dengan kandungan berkah yang tinggi, maka mereka akan meninggalkan barang dengan kandungan berkah yang rendah dan menggantinya dengan barang dengan kandungan berkahnya lebih tinggi. Dengan demikian, jika maslahah relatif turun, maka jumlah barang yang diminta akan turun juga, begitu juga sebaliknya.

\footnotetext{
${ }^{15}$ Rusdi, M. A. (2017). Maslahat Sebagai Metode Ijtihad Dan Tujuan Utama Hukum Islam. DIKTUM: Jurnal Syariah dan Hukum, 15(2), 151-168.
} 
Terdapat dua pendekatan untuk mengetahui perilaku konsumen, yaitu pendekatan maslahah marginal dan pendekatan iso-maslahah. Pendekatan pertama didasarkan pada pandangan bahwa manfaat ataupun berkah atas suatu kegiatan konsumsi bisa dirasakan dan diukur oleh konsumen. Sementara pendekatan yang kedua didasarkan pada pandangan bahwa maslahah, terutama berkah hanya bisa dirasakan, namun tidak bisa diukur seberapa besarnya. ${ }^{16}$ Seorang konsumen dalam memilih barang yang dikonsumsinya akan mempertimbangkan jumlah maslahah total yang akan diperolehnya yang paling tinggi. Jika terdapat peningkatan maslahah pada suatu barang/jasa, maka permintaan akan barang tersebut akan meningkat, dengan menganggap faktor lainnya tidak berubah.

Kurva iso-maslahah menunjukkan kombinasi dua barang/jasa yang memberikan maslahah yang sama. Untuk itu, setiap konsumen memiliki alternative kombinasi berbagai barang/jasa yang diperkirakan memberikan maslahah yang sama. Misal, Zaid membeli dua belas surat kabar dan satu makalah yang memberikan maslahah yang sama jika membeli enam surat kabar dan dua majalah. Kombinasi itulah yang disebut dengan iso-maslahah. ${ }^{17}$ Dalam dunia nyata, sebenarnya sulit menemukan barang-barang yang memiliki kandungan berkah yang benar-benar sama. Dalam hal ini, jika konsumen ingin meningkatkan maslahah yang ia peroleh, maka ia harus melakukan perubahan jumlah barang yang dibelanjakannya dalam komposisi yang berbeda.

Efek berkah terjadi setelah konsumen mencapai suatu kemaslahatan yang optimal maka kandungan berkah itu sangat mempengaruhi kecenderungan konsumen dalam memilih atau menentukan suatu barang yang akan dikonsumsinya karena para konsumen akan lebih memilih barang yang memiliki manfaat banyak bagi dirinya sehingga para konsumen akan merasakan efek berkah secara optimal dari barnag yang dikonsumsi tersebut. Efek berkah yang

16 Pusat Pengkajian dan Pengembangan Ekonomi Islam (P3EI), Ekonomi Islam (Jakarta: PT RajaGrafindo Persada, 2015), h. 181

17 Munrokhim, dkk, Ekonomi Islam, h. 182 
berpengaruh pada kepedulian sosial perusahaan terhadap pembelian. Karena perusahaan semakin memandang penting terhadap perlunya mereka dalam memperhatikan aspek lingkungan. Islam juga mengajarkan kalau keperdulian sosial ini sangat penting tidak hanya dalam keadaan berkecukupan tetapi meskipun dalam keadaan kesulitan.

Kepedulian perusahaan terhadap lingkungan ini adalah salah satu sumber peningkatan keberkahan karena ketika konsumen mengetahui bahwa kandungan berkah pada suatu barang meningkat maka ia akan meningkatkan pembelian atas barang tersebut dan akan mengurangi pembelian terhadap barang yang memiliki kandungan berkahnya yang lebih rendah. Oleh sebab itu disimpulkan bahwa peningkatan kandungan berkah suatu barang akan mempengaruhi peningkatan jumlah barang yang di minta oleh para komsumen. ${ }^{18}$

Di sisi lain, berkah marginal mempunyai sifat non decreasing. Hal ini member implikasi bahwa maslahah marginal mempunyai beberapa kemungkinan sifat, yaitu: konstan, meningkat, dan menurun. ${ }^{19}$

1. Kemampuan substitusi yang menurun (decreasing)

Jika berkah marginal (MB) bersifat increasing dengan tingkat pertumbuhan yang lebih rendah dari tingkat penurunan marginal manfaat duniawi (MF), maka maslahah marginal akan mengalami decreasing.

2. Kemampuan substitusi yang konstan

Jika berkah marginal (MB) bersifat increasing dengan tingkat pertumbuhan yang sama dengan tingkat penurunan marginal manfaat duniawi (MF), maka maslahah marginal akan konstan.

3. Kemampuan substitusi yang meningkat

Jika berkah marginal (MB) bersifat increasing dengan tingkat pertumbuhan yang lebih tinggi dari tingkat penurunan marginal manfaat fisik (MF), maka maslahah marginal akan increasing.

Adapun efek subtitusi dan efek pendapatan dari perubahan harga yaitu:

${ }^{18}$ Munrokhim, dkk, Ekonomi ..., h. 205

19 Munrokhim, dkk, Ekonomi ..., h. 190-191 


\section{Efek subtitusi}

Adanya gerakan dari satu titik keseimbangan yang lain dapat di pisahkan menjadi efek subsitusi dan efek pendapatan. Efek subtitusi mengatakan bahwa bila suatu komoditi turun individu akan menggantikan komoditi lain (jika harganya tetap) dengan komoditi lain. Efek subsitusi ini mengakibatkan kenaikan jumlah yang di minta atas komoditi yang harganya turun.

Adanya kenaikan harga suatu barang bisa di pandang sebagai penurunan maslahah total karena dengan anggaran yang sama konsumen akan mendapatkan manfaat yang lebih rendah atas barang yang di belinya. Adapun dengan adanya kenaikan harga suatu barang akan memiliki beberapa kemungkinan efek subtitusi yaitu:

a. Kenaikan harga suatu barang tanpa adanya perubahan kandungan maslahah.

Adanya kenaikan harga beras lokal akan mendorong konsumen untuk berpindah dari membeli beras lokal menuju beras impor.Hal ini di lakukan konsumen jika kebutuhan mereka tidak berubah.

b. Kenaikan harga barang di sertai dengan penurunan kandungan maslahah $^{20}$

Jika hal ini terjadi maka konsumen akan menurunkan jumlah pembelian barang untuk menghindari terjadinya penurunan maslahah.Sebagai misal naiknya harga kayu akan semakin langlangkanya pohon,bisa juga di ikuti oleh penebangan secara liar oleh para pedagang.Jika hal ini terjadi penurunan berkah pada kayu tersebut karena kayu di peroleh melalui proses yang titak di benarkan islam.

c. Kenaikan harga barang di sertai dengan kenaikan kandungan maslahah

Jika kenaikan harga suatu barang ini terjadi,sebagai misal ketika harga beras lokal naik di sertai dengan penggunaan pupuk organik yang tidak mencemari lingkungan (semula di gunakan pupuk kimiawi) maka

${ }^{20}$ Munrokhim, dkk, Ekonomi ..., h. 207 
konsumen muslim tidak langsung akan menurunkan jumlah pembelian beras lokal bahkan mungkin ia membeli beras dalam jumlah tetap. ${ }^{21}$

2. Efek pendapatan

Efek pendapatan mengakatan bahwa jika suatu komoditi turun (cateris parebus). Daya beli pendapatan uang yang tetap dari individu tersebut naik (pendapatan nik) jika hal ini terjadi konsumen cenderung membeli lebih banyak komoditi yang harganya turun jika barang tersebut adalah barang yang normal dan lebih sedikit jika barang tersebut inferior, sebagai misal apabila harga suatu komoditi normal turun efek pendapatan memperkuat efek subtitusi dalam menyebabkan liku permintaan individu akan komoditi tersebut berlereng negatif (individu membeli banyak komoditi yang harganya turun) sebaliknya bila harga suatu barang inferior turun efek pendapatan bergerak arah berlawanan dengan efek subtitusi. ${ }^{22}$

Islam mengharuskan orang untuk mengkonsumsi barang yang halal dan thayyib. Aturan islam melarang seorang muslim memakan barang yang haram, kecuali dalam keadaan darurat dimana apabila barang tersebut tidak dimakan, maka akan berpengaruh terhadap muslim tersebut. Di saat darurat seorang muslim dibolehkan mengkonsumsi barang haram secukupnya. Selain itu, dalam ajaran Islam, orang yang mempunyai uang banyak tidak serta merta diperbolehkan untuk membelanjakan uangnya untuk membeli apa saja dan dalam jumlah berapapun yang diinginkannya. Batasan anggaran (budget constrain) belum cukup dalam membatasi konsumsi. Batasan lain yang harus diperhatikan adalah bahwa seorang muslim tidak berlebihan (israf) dan harus mengutamakan kebaikan (maslahah). ${ }^{23}$

Dalam ajaran Islam, seseorang mempunyai pendapatan banyak tidak serta merta mereka diperbolehkan untuk mempergunakan uangnya untuk apa

\footnotetext{
21 Munrokhim, dkk, Ekonomi ..., h. 208

${ }^{22}$ Munrokhim, dkk, Ekonomi ..., h. 206

${ }^{23}$ Umar Faruq, Teori Permintaan dalam Ekonomi Islam dan Konvensional, http://umar-faruq/teori-permintaan-dalam-ekonomi-islam-dankonvensional/html, (Diakses pada tanggal 22 Oktober 2018)
} 
saja dan dalam jumlah berapa pun yang mereka inginkan. Batasan anggaran memang harus dipenuhi. Salah satu batasan lain yang harus diperhatikan adalah tidak boleh berlebih-lebihan atau israf. Secara umum, kriteria israf ini akan berbeda sesuai dengan kekayaan yang dimiliki oleh konsumen. Semakin kaya konsumen, maka batasan israf akan semakin meningkat meskipun ada batas maksimal pada tingkat tertentu.

Agar terhindar dari israf, maka terdapat prinsip-prinsip yang terus dipegang yaitu dalam mengkonsumsi sejumlah barang, maka harus bisa menciptakan maslahah. Adapun indikator yang bisa digunakan untuk menilai apakah konsumsi barang tersebut menciptakan maslahah atau tidak, antara lain:

1) Untuk barang lama (non-durable), maka konsumsinya tidak menimbulkan hal yang sia-sia.

2) Untuk barang habis pakai (durable), maka tingkat utilisasi tinggi.

3) Mencapai tingkat kelayakan yang standar atau lebih besar.

4) Menimbulkan opportunity cost yang tinggi jika tidak dikonsumsi.

5) Adanya maslahah yang tidak bisa dikategorikan pada keempat poin diatas. Misalnya, mengkonsumsi sesuatu barang dalam rangka memenuhi hobby yang halal atau mubah yang sifatnya spesifik. ${ }^{24}$

Kelima poin diatas tidak boleh dilandasi ataupun terkontaminasi dengan tujuan-tujuan yang batil. Selain itu, Islam juga menuntun agar kita peduli kepada orang lain, terutama sanak kerabat, tetangga, fakir miskin, anak yatim ataupun konsumen lainnya. Tingkat kepedulian ini akan mempengaruhi seberapa barang yang dibeli. Kepedulian ini dimaknai sebagai amal saleh, yaitu kemauan konsumen membelanjakan barang/jasa untuk memenuhi kebutuhan orang lain. Islam tidak menganjurkan permintaan terhadap suatu barang dengan tujuan kemegahan, kemewahan dan kemubadziran. Bahkan islam memerintahkan bagi yang sudah mencapai nisab, untuk menyisihkan dari anggarannya untuk membayar zakat, infak dan sedekah.

${ }^{24}$ Munrokhim, dkk, Ekonomi ..., h. 190-191 


\section{Penutup}

Permintaan merupakan jumlah atau kuaantitas barang dan jasa yang diminta oleh konsumen kepada produsen. Permintaan tersebut dipengaruhi oleh berbagai faktor antara lain harga barang itu sendiri, harga barang lain yang terkait, dan sebagainya. Konsep permintaan dengan menggunakan pendekatan maslahah maka konsumen dalam meminta atau membeli barang maupun jasa hendaknya menyesuaikan dengan kemampuannya. Di samping itu, agar dalam membeli barang hendaknya yang dapat memberikan kemashlahatan bagi dirinya dengan tidak berlebih-lebihan dan tetap memperhatikan hak-hak orang lain.

\section{Daftar Pustaka}

Bulan Purnama, Teori Permintaan Islami, http://makalahkite.blogspot.co.id/2013/12/teori-permintaan-islami.html (Diakses pada tanggal 22 November 2018)

Ekonomi Holic, Permintaan Penawaran dan Harga Keseimbangan, http://www.ekonomiholic.com/2015/01/permintaan-penawaran-hargakeseimbangan.html. (Diakses pada tanggal 17 Februari 2018).

Faruq, Umar, Teori Permintaan dalam Ekonomi Islam dan Konvensional, http://umar-faruq/teori-permintaan-dalam-ekonomi-islamdankonvensional/html, (Diakses pada tanggal 22 Oktober 2018)

Kardono-hunfil, Permintaan dan Penawaran, http://nuhfil.Lecture.ub.ac.id/files/2009/03/ mikro-2-penawaran-danpermintaan-nuhfil.pdf. (Diaksese pada tanggal 15 November 2018).

Kementerian Agama RI, Al-Qur'an Tajwid. Jakarta: Sygma Examedia Arkanleema, 2010.

Lipsey, Richarg G., et., al, eds, Pengantar Makroekonomi. Jakarta: Erlangga, 1993

Munrokhim Misanan dkk., Text Book Ekonomi Islam, (Yogyakarta: Direktorat Perbankan Syariah Bank Indonesia DPbS BI \& Pusat Pengkajian dan Pengembangan Ekonomi Islam Universitas Islam Indonesia (P3EI UII), h. 155-156. 
Pracoyo, Tri Kusnawangsih, dan Antyo Pracoyo, Aspek Dasar Ekonomi Mikro. Jakarta: PT Grasindo, 2006

Pusat Pengkajian dan Pengembangan Ekonomi Islam (P3EI), Ekonomi Islam. Jakarta: PT RajaGrafindo Persada, 2015

Rahmawati, Anita, Ekonomi Mikro Islam. Kudus: Nora Media Enterprise, 2011

Rusdi, M. A. (2017). Maslahat Sebagai Metode Ijtihad Dan Tujuan Utama Hukum Islam. DIKTUM: Jurnal Syariah dan Hukum, 15(2), 151-168.

Saldi, Fadli, Hukum Permintaan dan Penawaran, http://drfadli.blogdetik.com/ files/2010/05/ hukum-permintaandanpenawaran.pdf. (Diakses pada tanggal 23 November 2018).

Sukirno, Sadono, Mikroekonomi Teori Pengantar. Jakarta: RajaGrafindo Persada, 2010.

Suparmoko, Ekonomi. Bogor: Quadra, 2007 